\title{
Stock market volatility: comparison between Dhaka stock exchange and Chittagong stock exchange
}

\author{
Md. Ariful Islam ${ }^{1}$, Md. Rayhan Islam², Mahmudul Hasan Siddiqui ${ }^{3}$ \\ ${ }^{1}$ ASIC Bank Limited, Khulna, Bangladesh \\ ${ }^{2}$ Business Administration Discipline, Khulna University, Khulna-9208, Bangladesh \\ ${ }^{3}$ Unilever Bangladesh Limited, Gulshan-1, Dhaka-1212, Bangladesh
}

\section{Email address:}

arifrussell@yahoo.com (Md. A. Islam), rayhan_07@yahoo.com (Md. R. Islam), mhs.sadi@gmail.com (M. H. Siddiqui)

\section{To cite this article:}

Md. Ariful Islam, Md. Rayhan Islam, Mahmudul Hasan Siddiqui. Stock Market Volatility: Comparison Between Dhaka Stock Exchange and Chittagong Stock Exchange. International Journal of Economics, Finance and Management Sciences. Vol. 2, No. 1, 2014, pp. 43-52. doi: $10.11648 /$ j.ijefm.20140201.16

\begin{abstract}
This paper is a comparison the volatility of price between Dhaka stock exchange (DSE) and Chittagong Stock Exchange (CSE). I did this study on volatility as a part of academic course of Research Methodology and Dissertation. The main objective of this study is to determine whether the markets are same volatile or not. Volatility is the most basic statistical measure. It can be used to measure the market risk of a single instrument or entire portfolio of investment. Investors, regulators, brokers, dealers and the media have all express concern over the level of stock market volatility. After market crash of 1996, individuals as well as corporate investors along with the regulators have become conscious about the volatility and felt importance of information regarding market to take good investment decision. This paper also discussed about the preliminary concept of volatility. For analysis of data I have consider only year 2004. Standard deviation, coefficient of Variation, F-test and monthly return is calculated. All the result shows the same picture. CSE is more volatile than DSE. The CSE30 and DSE20 also show the same result. Interesting finding is that general price is less volatile than CSE30 and DSE20. It implies that the top 20 and 30 securities influence the whole market. If the price of these securities increases, the price index increases. Ups and downs of the price of these securities in CSE is higher than that of DSE. Although investors are suffering from lack of information about the quality of securities, they take investment decision considering the general price index of two markets. Some time it may mislead the investor the differences of indexes of two markets. As the base of these two indices is different they can consider the percentage change in indexes and standard deviation of the indexes. Though the calculation is based on only the index one individual investor can calculate the return from individual security and then can take the portfolio investment decision. In this study individual securities are not considered as it would take massive calculating and data collection operation. Despite of these limitations it can easily be told that Chittagong Stock Exchange is more volatile than Dhaka Stock Exchange.
\end{abstract}

Keywords: Stock Market, DSE, CSE, Volatility, Market Risk, Variation

\section{Introduction}

\subsection{Study Area}

In case of study on any discipline, the co-ordination of both theory and practice gets due importance in the modern world. To bridge the gap between theory and practice the students of Masters in Bank Management (MBM) of Bangladesh Institution of bank Management (BIBM) have to study on some economic or finance and banking related issues for partial fulfilment of Research Methodology and Dissertation course. After getting consent of guide teacher I have chosen the Stock market as my study area. Stock market is a vast issue; therefore I have selected a specific area 'Volatility of Stock market' that is approved by my guide teacher.

As I did this study on 'Volatility of Stock market' for academic purpose within the limited time, this is conducted mainly basis on the Price Indices of Dhaka Stock Exchange (DSE) and Chittagong Stock Exchange (CSE) and these indices are collected from the Daily Financial Express.

\subsection{Study Objectives}

DSE and CSE are the two stock exchange of Bangladesh. 
For the development of capital market of Bangladesh DSE was established in 1954. Up to December/2004 there is 237 listed companies, 11 mutual funds and 8 debentures in DSE. CSE was established in 1995 after successful operation of DSE and to meet the increased demand of expanded capital market. . There is 198 listed companies 11 mutual funds and 2 debentures in CSE. In our country investors are not so award about the factors what should be considered to take an investment decision either in primary market or in secondary market. Consequences of this unawareness in 1999 the capital market was depressed and investors lose their investment. To ensure the investors' interest and operating in trading a lot of measures was taken by Security Exchange Commission (SEC) like Central Depository System (CDS), screen based operating system, etc. But over the all measures investor has to know the risk and return associated with their investment. For that purpose knowing about volatility of price is very important.

The main objective of the study is to know about the security market of Bangladesh, volatility and to compare the volatility of two security markets. Identification of the problems regarding the volatility and suggestions to the investors in this regard there are also the prime objectives of this study. There are some specific objectives those are set to attain the major objectives:

1. To provide an overview of security markets of Bangladesh

2. To provide an overview of volatility of stock exchange

3. To acquaint with the technique of calculation of volatility

To develop knowledge about the volatility of stock exchange.

\subsection{Operational Definition of Important Terms}

Market Capitalization: Market Capitalization is the sum of the market value of all stocks included in the index. The market value of each stock is equal to,

\section{$\mathrm{Pi} * \mathrm{Ni}$}

Where, $\mathrm{Pi}=$ the last transaction price for the stock in period i.

$\mathrm{Ni}=$ the number of shares issued and outstanding at the end of the period $\mathrm{i}$

Turn Over: The value or volume of outstanding shares traded in a particular stock exchange during a period of time.

Amount Traded: Amount traded means market value of securities traded on the floors of a security exchange.

Stock Market Index: A stock market index is a number that indicates the relative level of prices or value of securities in a market on a particular day compared with a base-day figure, which is usually 100 or 1000 . There are many different ways of constructing an index. One of the most common methods is,

Index of a particular day $=$ (Portfolio value of a particular day/ Base Day's portfolio value)*Base Day's index.

\subsection{Methodology}

Both statistical and graphical approach is used in this study. As it is a comparison between two stock markets and a wide range of data has been considered, hypothesis is tested by F-test, and line graph is used.

\subsubsection{Procedure Used}

To compare the volatility of the DSE and the CSE in this study, standard deviation of general price index, DSE20 and CSE30 has considered. The standard deviation is calculated by adding squired value of all differences of daily price index from its geometric mean divided by the n1. Then the value is squired rooted.

\subsubsection{Population and Sample of the Study}

In this study the general index of DSE and CSE has considered as population. DSE-20 and CSE-30 indices are also considered. The daily price index throughout the year 2004 is the sample which selected judgemental basis for convenience and to restrict the study within limited boundaries.

\subsubsection{Source of Data}

Secondary data is used in this study and has collected from the Daily Financial Express.

\subsubsection{Quality and Representativeness of Data}

The data is more reliable than any other published secondary source but due to unavailability of a few days newspaper there is a lack of an ignorable percentage of data.

\subsubsection{Statistical Tools Used for Analysis}

To test whether there is variation between these two stock markets $F$ test has been used. Coefficient of Variation (CV), Standard Deviation (SD) and graphical presentation is used to compare two stock exchanges.

\subsection{Limitations}

In this study, a whole-hearted effort was applied to collect, organize, analyze, and interpret the related data and finally to attain the optimum outcome of the research. In spite of these efforts, there exist some limitations that acted as a barrier to conduct the research. These limitations are:

ㅁ The time allocated for the study was limited. It is tough to work with the history of the security market and its reforms only within three months in the midst of two other courses.

ㅁ All data are secondary and thus problems were faced in collection of data.

\subsection{Importance of the Study}

In its role as the capital market DES and CSE tries to satisfy the need of entrepreneurs and the investors by accumulating capital and ensuring safe and sustaining return. Volatility of stock return has been mainly studied in developed economies. There is relatively a few empirical research has been conducted on stock return volatility in 
the Bangladeshi market context. So it is important to investigate the pattern of volatility in the Bangladeshi stock market specially during the 1998-2004. This study simply giving a touch toward a large study analysing the data of year 2004.

\section{Literature Review}

Akhter and Quddus (1996) reveal that initial subscriber obtain the same return whenever they dispose of their shares in Initial Public Offerings (IPOs) in a short period of about five or six months. They used mean adjusted performance index to analyze price behaviour of unseasoned new issues from the point of view of initial subscribers who are interested only in short-run. They found that the standardized mean excess return were virtually the same in first 30 trading days and concluding 30 trading days of the first 100 trading days since debut.

Imam and Amin (2004) found that the volatility of the stock return of Bangladesh Capital Market follows a generalized autoregressive conditional heteroskedastic (GARCH) process. It has been observed that the volatility predicted this period has more influence in forecasting volatility for the next period. For the DSE return series volatility clustering is said to be persistence implying that in Dhaka Stock Market today's return has a large effect on the conditional forecast variance many periods in the future The GARCH model for the two sub-periods of pre-crash and post-crash shows different result. The reason for such structural shifts in GRACH process may be due to high volatility in return series in the later period and to the change in the behaviour of investor after the stock market crash in 1996. Passive role-played by the institutional investors, lack of confidence by the long-term individual investors and the dominance of speculators, among many, are the notable reasons for the change in investor's behaviour. Tests for non-stationarity indicated that the conditional volatility of DSE index in post-crash period in mean reverting. This finding suggests that current information has no effect on long run forecasts, rather, volatility shocks (random error) than the volatility estimated at earlier period influence more in estimating future volatility.

Kaur (2004) found that like many major developed and emerging stock markets volatility of Indian stock markets behave same. Volatility clustering, i, e., shocks to the volatility process persists and the response to news arrival is asymmetrical, meaning that the impact of good and bad news is not same. Sayed (2002) works on the recent selective external and monetary measures that influence the investors and may create the market-oriented environment to invest money in the stock market of Bangladesh. He said that the portfolio is mainly limited to land, commodities, real assets, banks and National Savings Directorate (NSD) certificates due to need of financial innovations. Therefore, actions of the monetary sector largely influence the flow of funds. In Bangladesh, flow of cash is not generally based on past profit and thus the credit markets have greater impact on the retained earnings of the firms.

Kearney and Daly (1998) examines the extent to which the conditional volatility of stock market returns in a small, internationally integrated stock market are related to the conditional volatility of finance and business cycle volatility. It employs a low frequency monthly dataset for Australia including stock market returns, interest rates, inflation, the money supply, industrial production and the current account deficit. Among these variables, the strong effect is found to be from the conditional volatility of the money supply to the conditional volatility of the stock market. By contrast, no evidence is found of volatility spillover from the foreign exchange market to the stock market in Australia.

Masulis and Huang (1999) examine the relation between stock price volatility and trading activity on the London Stock Exchange. They found that the number of small trades and their average size significantly impact price volatility. Again splitting the small trade category into relatively smaller and larger trades, they found that only for larger trades, close to the maximum guaranteed depth of existing quotes, are there significance positive impacts on stock price volatility from both the trade frequency and average trade size..

\section{An Overview of Bangladesh security Markets}

\subsection{Financial System of Bangladesh: Basic Concept}

The financial system is a set of institutional arrangement through financial surpluses in the economy are mobilized from surplus units and transferred to deficit spenders. Creating and supporting efficient financial systems should be a high priority in development. Much of the wealth of developing countries remains invested in traditional savings vehicles such as gold, land, or "cash under the mattress". But formal savings systems provide a more productive and often safer conduit for funds than these other alternatives. The formal financial system when efficient, well regulated, and competitive or at least contestable can offer lower intermediation costs than informal channels. The main constituents of any financial system are: financial institutions, financial instruments and financial markets.

Financial Institutions: The modern name of financial institution is financial intermediary, it mediates or stands between ultimate borrowers and ultimate lenders. Financial institutions are generally classified under two main heads: a) Banks and b) Non-Bank Financial Intermediaries. Financial intermediaries include banks (central bank, commercial banks, investment banks etc.), Securities and Exchange Commission (SEC), specialised financial institutions, development financial institutions and institutional investors (i.e. Investment Corporation of Bangladesh).

Financial Instruments: Financial Instrument is the financial claim of the holder against the issuer. Financial 
Instruments are of two types: Primary or Direct and Secondary or Indirect Financial Instruments.

Primary or direct financial instruments are financial claims against real sector units.

Secondary or indirect financial instruments are financial claims against financial institutions or intermediaries.

Financial Markets: Financial market is the market where financial instruments are purchased and sold. The market can be classified into a number of ways, but from the duration point of view, it is classified into two: money market and capital market.

(1) Money market is a market where financial securities maturing in less than one year that is short-term fund are transacted. Typical money market instruments are certificates of deposits, treasury bills, post office savings etc.

(2) The Capital market is a market for long-term funds. It facilitates an efficient transfer of resources from savers to investors and becomes conduits for channelling investment funds from investors to borrowers. The capital market is required to meet at least two basic requirements: (a) it should support industrialisation through savings mobilisation, investment fund allocation and maturity transformation and (b) it must be safe and efficient in discharging the aforesaid function. It has two segments, namely, securities segments and non-securities segments.

Securities Segments - The securities segment is concerned with the process a firm distributes its securities to the public in the primary market and the securities are then traded in the secondary markets. Financial intermediaries, such as merchant banks, Asset Management Company, underwriters, broker-members etc. are involved in the process. Securities segments of capital market have two important roles to play: (a) information production and (b) monitoring. Security segment of the markets can be divided into two:

(1) Primary or New Issue Market: The market in which newly issued securities are sold by their issuers, who received the proceeds. Securities are issued in the primary market by one or more of the following methods:

(a) Public Issue: An offer to the public by an issuer through a prospectus for subscription. This is the most common method of primary market placement in Bangladesh.

(b) Private Placement: An offer to specific known persons selected by the sponsors for procuring subscription.

(c) Right Issue: An offer in which existing shareholders are offered new securities in proportion to their existing holdings.

(d) Offer for Sale: An invitation to the general public to purchase the stock of a company through an intermediary.

(2) Secondary Market: Market that permits trading in outstanding issues; that is, stocks or bonds already sold to the public are traded between current and potential owners. The proceeds from a sale in the secondary market do not go to the issuing unit, but rather to the current owner of the security. Again secondary market has four parts:

(a) Organized Stock Exchange: Securities are traded according to organized rules and regulations.

(b) Over-the-counter (OTC) Market: OTC market includes trading in all stocks not listed on one of the exchanges. The OTC market is not a formal organization with membership requirements or a specific list of stocks deemed eligible for trading. In theory, any security can be traded on the OTC market as long as a registered is willing to make a market in the security (willing to buy and sell shares of the stocks). Generally companies which are unable and unwilling to enlist, float their shares in the OTC market.

(c) Third Market: The term third market describes overthe-counter trading of shares listed on an exchange.

(d) Fourth Market: The term fourth market describes direct trading of securities between two parties with no broker intermediary. In all most all cases, both parties involved are institutions.

Non-securities Segments - are those markets in which loan / equity loan are provided by the banks and financial institutions, such as Nationalized Commercial Banks (NCBs), Development Financial Institutions (DFIs), Private Commercial Banks (PCBs), Investment Corporation of Bangladesh (ICB). Broadly non-security segments are divided into two parts: (a) Banking Financial Institutions and (b) Non-Banking Financial Institutions. We need to recognize that conditions in the bank-based system are unpalatable in the sense of huge non-performing loans, high degree of classified and default loans, capital inadequacy of banks and the like.

\subsection{Operational Procedures in Primary and Secondary Markets}

Securities market operation means primary and secondary market operations. Affairs of the primary market can be handled easily. The entire process of allotment is executed under the instruction of the regulatory authority. SEC has been successful in obtaining maximum disclosure through prospectus, which is approved by them. Primary market is also a one-way traffic. It is the secondary market where lie all actions, thrill and tensions. In fact secondary market is a complex one. It may have the problem of inside trading, market rigging and manipulation and what not? Hence the regulating authority's main thrust is upon the rules and regulations of the bourses, obviously with a view to protecting the interest of the investors. Most of these are prepared by the bourses themselves as Self-Regulatory Organization (SRO). The floor where the secondary market operations conducted is known as stock exchange, in French it is "Bourse" and "Bolsa" in Latin America.

The stock exchange has been operating for the last three centuries and the number is increasing day by day. During this long period there has been a sea change in the 
operational procedure of the stock exchanges. In earlier days how did it operate? Let us read the following comments on London Stock Exchange by an anonymous commentator in 1695, "The howling of the wolf, the grunting of the dog, the braying of the ass, the nocturnal wooing of the cat, all these in unison could not be more hideous than the noise which these being make in the Stock Exchange"

But now electronic media and state of the art technology on securities market have brought tremendous changes. In most developed countries the investors no more rush to the stock exchanges. Even brokers do not bother to go there rather transactions are carried through computer terminal and deals are auto matched. Some countries have even adopted scrip less trading. 'Central Share Depositories' maintain record through book entries of distinctive numbers and shares have been dematerialized. Here in DSE (Dhaka Stock Exchange) and CSE (Chittagong Stock Exchange) trading system is fully automated screen based. Both the Stock Exchanges of Bangladesh provide Clearing Services for members through their Clearing Houses. The Clearing House acts as a common agent between members by delivering and receiving their securities/cheques. Custodian services in Bangladesh are provided by the Standard Chartered Bank. The following services are available to foreign investors: 1) Settlement, 2) Safekeeping, 3) Registration, 4) Corporate Actions, 5) Proxy Voting, 6) Client Reporting, 7) Cash Management, 8) Market information. Under Securities and Exchange Commission Act, 1993 all players of the securities markets, like brokers, managers to issues, underwriters, investment advisors are to obtain licenses from SEC.

\subsection{Trading Period}

\subsubsection{Pre-Opening Session}

Order entry, deletion/modification of limit orders is only permitted; execution of orders shall not be done during this session. The previous day's closing price and index will be available to the dealers/brokers during this session.

\subsubsection{Opening Session}

During this session Matching of orders shall be done at opening price. The opening price of a security shall be the price at which maximum number of securities is matched. In the event of being no trade for certain securities, then the last closing price for the security shall be made the opening price for the day. No order entry shall be permitted during this session.

\subsubsection{Continuous Trading Session}

Orders shall be executed during this session and if an order can not be executed in whole or in part, then it will be stored as an unfilled order. Unfilled orders from the preopening session shall be carried forward with time stamp to this session.

\subsubsection{Closing Session}

No order is received in this session. Pending orders executable at closing price and orders 'match at closing price' shall be executed in this session.

\subsubsection{Close Price Trading Session}

Only 'match at closing price' order and all executable pending orders shall be executed in this Session at closing price. If any 'match at closing price' order is not executed in whole or in part, it will be removed from the system automatically and all other pending orders except the expired ones shall be carried forward to the following Trading Day.

\subsubsection{Post-Closing Session}

The trading members will make enquiries, verify, and down load the daily transaction details in this session.

\subsection{International Framework}

A comparison of the microstructure, architecture, and regulatory environment of the security market of Bangladesh with emerging and developed markets implies that the determinants of growth of capital markets in Asia may be structural as well as economic. A well-designed regulatory structure is necessary to reach an optimal balance between agency costs of capital formation and monitoring costs imposed by regulation. In the absence of regulation, wealth transfers between shareholders, debt holders, and management may occur that raise the cost of capital to corporations and lower investment in productive assets. Excessive and inappropriate regulations are associated with high monitoring costs to corporations because they limit the ability of the market to attract new capital. What may be less widely acknowledged is that not only the regulatory structure but the market microstructure and organization also have the ability to promote or hinder economic development by acting through the cost of capital. Proper design of the trading mechanism and clearing function promotes liquidity, low transaction costs, low frictional losses, and fewer mispricing episodes. Thus, we can say that the liberalization and reform of capital markets in Bangladesh may fail to deliver the desired results without structural and regulatory changes to the market. There are mainly three organizations involved in security market: (1) Securities and Exchange Commission (SEC), (2) Dhaka Stock Exchange (DSE) and (3) Chittagong Stock Exchange (CSE).

\subsection{Securities and Exchange Commission (SEC)}

In order to protect the interest of investors in securities, and to develop a viable securities market the Securities and Exchange Commission (SEC) was established on 8th June of 1993 under the Securities and Exchange Commission Act. Consistent with overall policies, SEC is supposed to act as a central regulatory agency performing wide range of functions covering the entire capital market including the proper issue of capital, the establishment of fair trading practices and the close supervision of issuers, markets and intermediaries 
Monitoring and supervision by the commission

The Commission monitored compliance of laws by public listed companies, stock exchanges and stockbrokers/dealers. Among others [13], the Commission monitored whether-

* annual general meetings (AGMs) were held on time by public listed companies;

* declared dividends were paid on time by public listed companies;

* refunds made and allotment letters issued against IPO on time by public listed companies;

* share certificates were issued on time by public listed companies;

* funds raised by IPO or right share were utilized by public listed companies as per financial and physical plans approved by the Commission;

* half-yearly accounts were issued by public listed companies on time;

* financial statements complied with the disclosure requirements prescribed by law;

* there were unusual fluctuations in the stock prices without known reasons;

* right shares were issued by public listed companies complying with the prescribed requirements; and

* interest on, and principal of, debentures were paid by public listed companies as per terms of debenture.

\subsection{Dhaka Stock Exchange}

In the early part of 1952, about five years after the independence of erstwhile Pakistan in 1947, the East Pakistan Stock Exchange Association Ltd., an independent Stock Exchange, was incorporated on April 28, 1954. It changed name to the East Pakistan Stock Exchange Ltd. on June 23, 1962 and finally to its present name of the Dhaka Stock Exchange Ltd. on May 14, 1964. However, formal trading began in 1956 with 196 securities listed on the DSE with a total paid up capital of about Taka 4 billion. After 1971, the trading activities of the Stock Exchange remained suppressed until 1976 due to the liberation war and the economic policy pursued by the then government. The trading activities resumed in 1976 with only 9 companies listed, having a paid up capital of Taka 137.52 million on the stock exchange. The total numbers of securities listed with the DSE stood at 267 in March 2004 against 260 securities in June 2003. As of March 2004 the issued capital and debenture of listed securities amounted to Tk. 4723.30 crore as compared with the Tk. 3608.10 crore in June 2003 registering an increase of 30.91 percent. As of March 2004 the market capitalization of all securities stood at Tk. 10042.90 crore which was Tk. 7299.80 crore in June 2003 showing an increase of 37.58 percent the weighted average share price index in June 2003 was 823.14 against 973.88 March 2004 in June 2003.

The Dhaka Stock Exchange (DSE) is registered as a Public Limited Company and its activities are regulated by its Articles of Association and its own rules, regulations, and by-laws along with the Securities and Exchange
Ordinance, 1969; the Companies Act, 1994; and the Securities and Exchange Commission Act, 1993 (DSE, 1999). As per the DSE Article 105B, its management is separated from the Council. The executive power of the DSE is vested with the Chief Executive Officer (CEO). The CEO is appointed by the Board with the approval of the SEC. Following graph shows the year wise price index of DSE.

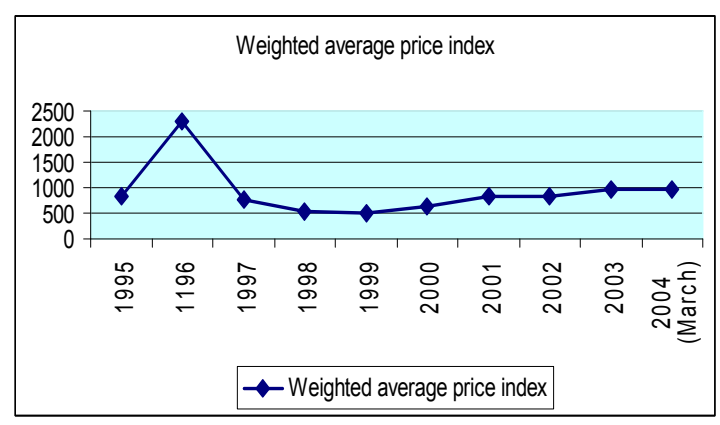

Graph-1

\subsection{Chittagong Stock Exchange (CSE)}

The Chittagong Stock Exchange (CSE) was registered as a public limited company and incorporated on $1^{\text {st }}$ April 1995.In the backdrop of a strong need to institute a dynamic automated and transparent stock exchange in the country, 70 reputed business personalities established this bourse in the commercial capital Chittagong. Only 30 securities were listed on the first day trade when market capitalization stood at $\$ 0.2$ billion. The trading operations of the exchange are fully automated from 1998. CSE is a self-regulated non-profit organization. A 24 member Board of Directors manages its business out of which 12 are elected from the members, and 12 are nominated from the non-members by SEC. The number of members is 129 . The foreigners can also become members of CSE. It has provision for 500 members; all members shall be body corporate. The executive power of CSE is vested with the Chief Executive Officer (CEO). The CEO is appointed by the Board with the consent of SEC. The authorized and paid up capitals of CSE are Tk.150.00 million and Tk.38.40 million respectively.

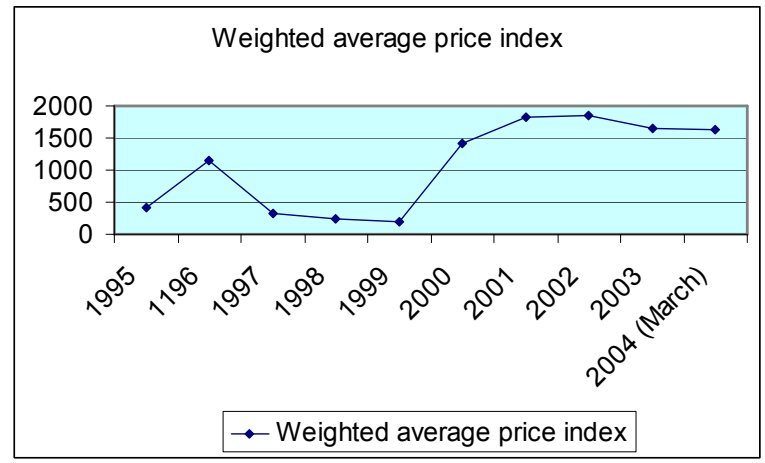

Graph-2 
The total number of securities listed with the Chittagong Stock Exchange in March 2004 stood at 200 against 195 securities in June 2003. As of March 2004 market capitalization of all securities stood at Tk. crore against Tk. 6020.86 crore in June 2003 register an increase of 7.15 percent. The weighted average share price index in March 2004 was 1630.93 against 1642.78 in June 2003.

\section{Concept of Volatility}

Volatility is the most basic statistical measure. It can be used to measure the market risk of a single instrument or an entire portfolio of instruments. While volatility can be expressed in different ways, statistically, volatility of a random variable is its standard deviation. In day-to-day practice, volatility is calculated for all sorts of random financial variables such as stock return, interest rate, the market value of portfolio, etc. stock return volatility measures the random variability of the stock returns. Simply put stock return volatility in the variation of the stock return in time. More specifically, it is the standard deviation of the daily stock return around the mean value and the stock market volatility in the return volatility of the aggregate market portfolio.

\subsection{Components of Stock Market Volatility}

Researchers have sought to analyze the relative importance of economy-wide factors, industry-specific factors, and firm-specific factors on a stock's volatility. This approach borrows from modern asset pricing theory and its emphasis on so-called factor models, or models that assume a firm's stock return is governed by factors such as the overall market return, the return on a portfolio of firms sampled from the same industry, or even changes in economic factors such as inflation, changes in oil prices, or growth in industrial production. If returns have a factor structure, then the return volatility will depend on the volatilities of those factors. Campbell, et al. (2001) assume the factors are the overall market return, an industry return (e.g., financial, industrial, etc.), and an idiosyncratic noise term that captures firm-specific information. They document the important empirical fact that while volatility moves considerably over time, there is not a distinct trend upwards or downwards. More interestingly, however, since 1962, there has been a steady decline in stock market volatility attributed to the overall market factor; that is, the common volatility shared across returns on different stocks has diminished over that period. The variation ascribed to firm-specific sources, by contrast, has risen. The implication for investors, then, is that they need to hold more stocks in their portfolios in order to achieve diversification.

\subsection{Stock Market Volatility and Dividends}

Stock market performance is usually measured by the percentage change in the stock price or index value, that is, the returns, over a set period of time. One commonly used measure of volatility is the standard deviation of returns, which measures the dispersion of returns from an average.

If the stock market is efficient, then the volatility of stock returns should be related to the volatility of the variables that affect asset prices. One candidate variable is dividends. But research conducted in the early 1980s suggests that variation in dividends alone cannot fully account for the variation in prices (see Le Roy and Porter 1981 and Shiller 1981). Prices are much more variable than are the changes in future dividends that should be capitalized into prices. Asset prices apparently tend to make long-lived swings away from their fundamental values. This fact turned out to be equivalent to the finding that, at long horizons, stock returns displayed predictability. Thus, the literature on excess volatility broached the possibility that the stock market may not be efficient.

In the excess volatility literature, it was seen that the dividends that are capitalized in the stock price arrive in the future and need to be "discounted" back to the present using a discount rate (Krainer 2002). In the early research it was assumed that this discount rate was constant. However, discount rates depend on investors' preferences for risk, which could very well change over time. Therefore, stock market volatility may not be excessive if discount rates are variable enough. Thus, the real contribution of the excess volatility literature was to call attention to the fact that corporate dividends are simply too smooth a series to account for the high volatility in prices. Subsequent research necessarily focused away from the payout policy of firms and toward the characteristics of investors and of actual stock market trading.

\subsection{Indexes}

In analyzing volatility of security markets of Bangladesh, this report is based on the analysis of indexes of two security markets of Bangladesh. Rather considering individual stock, the portfolio (all treaded stocks, Debentures and mutual funds) is considered. Each market calculates two indexes. DSE use General Price Index and DSE20. CSE use General Price Index and CSE30. DSE20 represents the top 20 stocks of DSE and CSE30 represents top 30. Both the bourses of the country introduced SEC prescribed index under weighted average method and excluded ' $Z$ Group' shares from the calculation list since November 2001. Both the indices have replaced the conventional age-old all share price indices which had been as the benchmark barometer of the bourses. DSE named the new index as Weighted Average Share Price Index and the base index has been calculated at 817.62 points while the CSE calls the new index Trade Volume Weighted Index, which stood at 1836.72 points on the close of first day trading. SEC termed the new move as an attempt to arrest any bid to bring down or push share prices up by trading a small number of shares.

These security-market indexes have five major specific uses. These are, 
* To examine total returns for an aggregate market or some components of a market over a specified time period and use the rates of return computed as a benchmark to judge the performance of individual portfolios.

* To develop an index portfolio. Index portfolio led to the creation of index funds to track the performance of the specified market series (index) over time.

* To examine the factors that influence aggregate security price movement by securitises analysts, portfolio managers and others use security-market indexes.

* To project future stock price movements, technicians would plot and analyze price and volume changes for a stock market series.

* An individual risky asset is its systematic risk, which is the relationship between the rates of return for a risky asset and the rates of return for a market portfolio of risky asset. Therefore it is necessary when computing the systematic risk of an individual risky asset (security) to relate its return to the returns for an aggregate market index that is used as a proxy for the market portfolio of risky assets.

\subsection{Persistence of Stock Market Volatility}

Stock market volatility tends to be persistent; that is, periods of high volatility as well as low volatility tend to last for months. In particular, periods of high volatility tend to occur when stock prices are falling and during recessions. Stock market volatility also is positively related to volatility in economic variables, such as inflation, industrial production, and debt levels in the corporate sector (see Schwert 1989).

The persistence in volatility is not surprising: stock market volatility should depend on the overall health of the economy, and real economic variables themselves tend to display persistence. The persistence of stock market return volatility has two interesting implications. First, volatility is a proxy for investment risk. Persistence in volatility implies that the risk and return trade-off changes in a predictable way over the business cycle. Second, the persistence in volatility can be used to predict future economic variables. For example, Campbell, et al. (2001) show that stock market volatility helps to predict GDP growth.

\section{Analysis and Findings}

\subsection{F-test}

The null Hypothesis is there is no variation between the mean return of DSE and CSE. Variation of DSE is equal to the variance of CSE. Volatility of both markets is same. So the alternative hypothesis is Volatility of both markets is different the computed value of test statistic is 3.5544 which is greater than the critical value 1.00 at $10 \%$ level of significance. The null hypothesis is rejected and alternative hypothesis accepted. There is variation between the mean return of DSE and CSE.

\subsection{Volatility and Comparison between DSE and CSE}

The following table shows the standard deviation from average index of each month of 2004 for DSE, CSE, DSE20 and CSE30.

\begin{tabular}{lllll}
\hline Month & $\begin{array}{l}\text { SD from } \\
\text { General } \\
\text { price } \\
\text { index of } \\
\text { DSE }\end{array}$ & $\begin{array}{l}\text { SD from } \\
\text { General } \\
\text { price index } \\
\text { of CSE }\end{array}$ & $\begin{array}{l}\text { SD from } \\
\text { General } \\
\text { price } \\
\text { index of } \\
\text { DSE-20 }\end{array}$ & $\begin{array}{l}\text { SD General } \\
\text { price index } \\
\text { of CSE-30 }\end{array}$ \\
\hline January & 6.52 & 15.896 & 8.9347 & 16.1235 \\
February & 24.0362 & 24.3875 & 12.9435 & 22.2344 \\
March & 9.4551 & 14.1435 & 14.9142 & 22.3505 \\
April & 34.5483 & 67.8144 & 36.4729 & 60.5687 \\
May & 20.3639 & 43.4381 & 67.5262 & 40.5833 \\
June & 42.5552 & 74.5427 & 42.7699 & 104.6256 \\
July & 14.9139 & 28.4582 & 18.645 & 35.0565 \\
August & 55.2672 & 114.9357 & 67.0889 & 154.8239 \\
September & 55.9362 & 108.1055 & 44.5722 & 101.1496 \\
October & 57.3651 & 75.3925 & 30.2654 & 70.917 \\
November & 71.7838 & 126.3259 & 84.4356 & 129.6821 \\
December & 27.5188 & 76.8292 & 27.3749 & 27.3749 \\
\hline
\end{tabular}
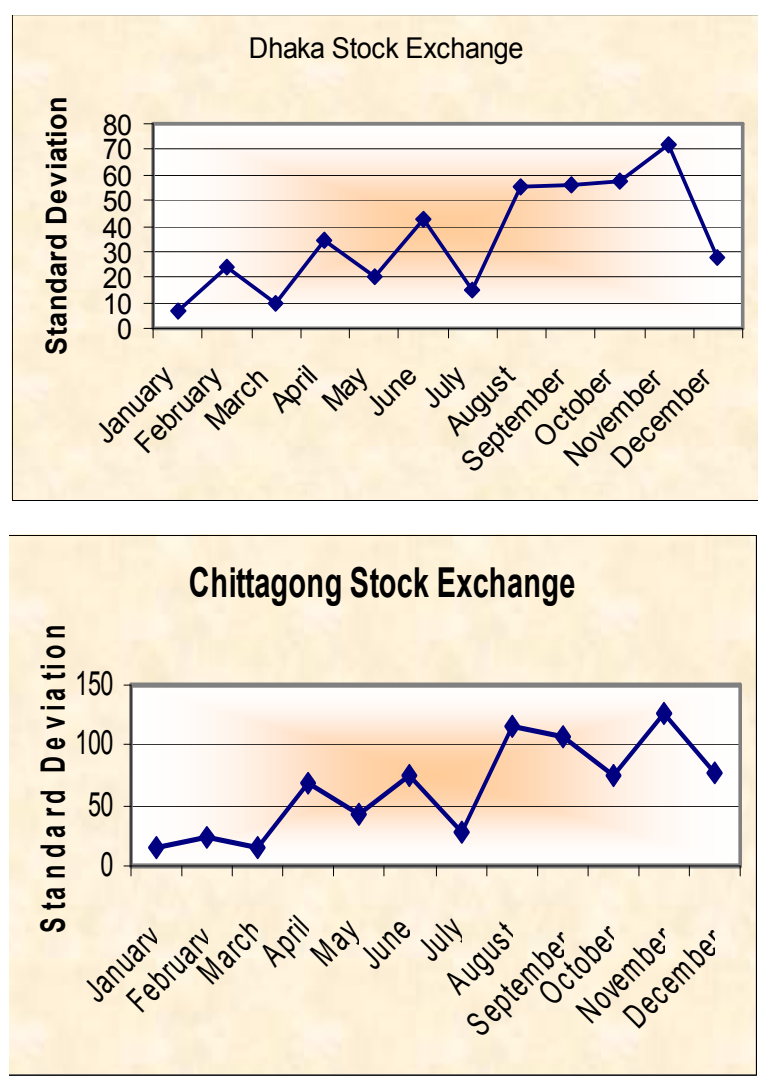

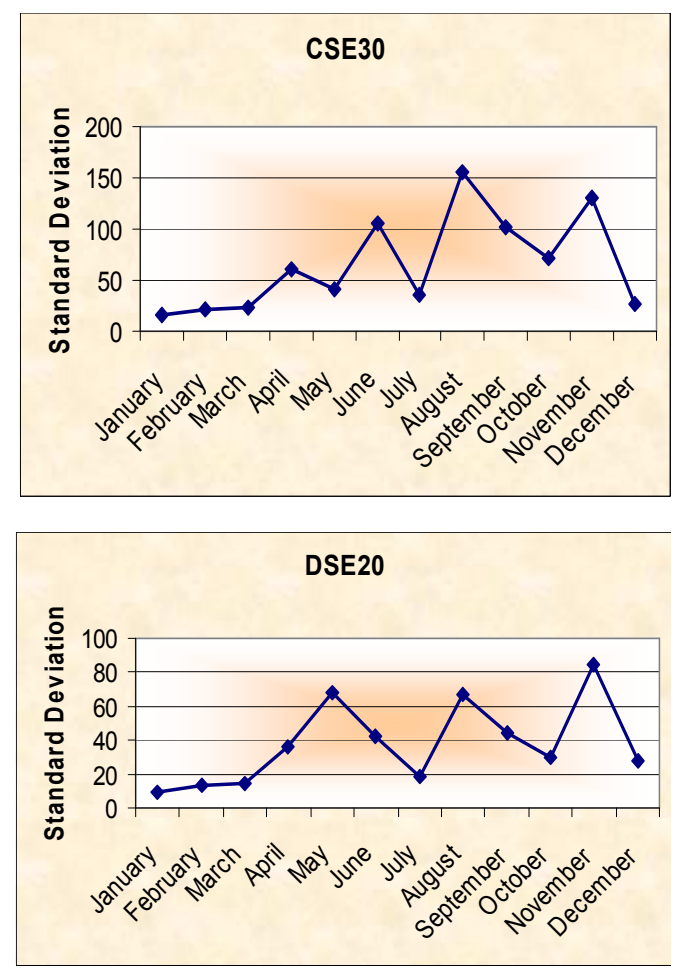

Standard deviation of the price index of DSE and CSE shows the ups and down between months and continuous trend to grow. The more the standard deviation more the price volatility. As the base of the indexes are not same so to compare between DSE and CSE we should consider the Coefficient of Variations (CVs) of these two markets. Following graphs shows the relationship of general price index of DSE - CSE and DSE20-CSE-30.

\begin{tabular}{lll}
\hline Month & CV-DSE & CV-CSE \\
\hline January & 0.6834 & 0.9937 \\
February & 2.5434 & 1.5278 \\
March & 0.9778 & 0.8783 \\
April & 3.2835 & 3.8432 \\
May & 1.7643 & 2.1904 \\
June & 3.3482 & 3.3316 \\
July & 1.1760 & 1.2725 \\
August & 3.9111 & 4.6958 \\
September & 3.5329 & 3.8195 \\
October & 3.3645 & 2.5049 \\
November & 3.9387 & 3.9092 \\
December & 1.4204 & 2.1919 \\
\hline
\end{tabular}



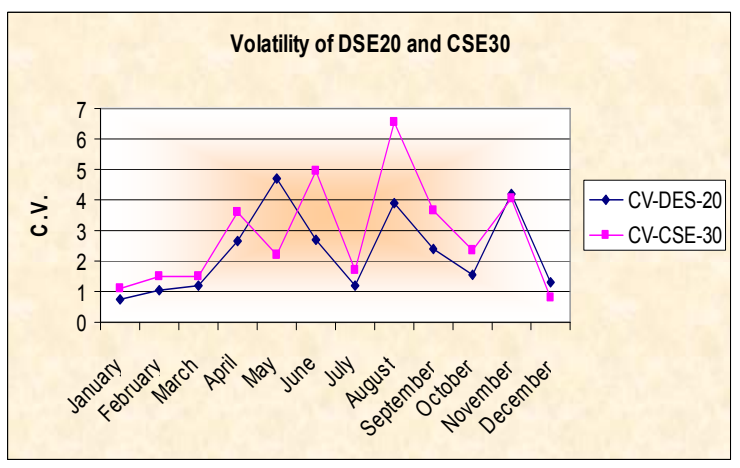

The tables and graphs show that CV of CSE is more than DSE. It implies that the stock price at CSE is more volatile than DSE. Even the stock price of leading companies (top 20 and 30 companies of DSE and CSE) also varies from DSE to CSE and the volatility is much high than CSE30 of DSE20.

\section{Conclusion}

Economists have long been interested in the patterns of stock market volatility. Their research on excess volatility relative to dividends found that volatility tends to ebb and flow; subsequent research found that periods of high volatility are persistent and occur during periods of stock market declines, and that the stock market volatility associated with systematic factors has been declining over time. These academic findings may offer little consolation to today's investor for whom volatility means portfolio losses, but the research has yielded important insights into how stock market information can help forecast economic variables, and how investors can construct portfolios that can minimize volatility. Credit market has a great impact on retained earnings of the firm and so stock price. Even little change in interest rate has an impact on stock market as the information is not so available and asymmetric. Credit market is affected from various problem like Moral Hazard between the lenders and borrowers, Costly monitoring, Default loans, and lower amount of foreign reserves.

Although investors are suffering from lack of information about the quality of securities, they take investment decision considering the general price index of two markets. Some time it may mislead the investor the differences of indexes of two markets. As the base of these two indexes are different they can consider the percentage change in indexes and standard deviation of the indexes. Though the calculation is based on only the index one individual investor can calculate the return from individual security and then can take the portfolio investment decision. In this study individual securities are not considered as it would take massive calculating and data collection operation. Despite of these limitations it can easily be told that Chittagong Stock Exchange is more volatile than Dhaka Stick Exchange. 


\section{Suggestions}

To reduce the volatility and to help the investors taking good investment decisions the following points may be considered:

1. Trading of the stock of those companies should be suspended who do not call AGM and distribute dividend.

2. Before going IPO it should be carefully checked by the SEC whether they have capacity to offer according to law.

3. Accounts of listed company should audited by renowned audit firm and to ensure whether the information are sufficiently disclose.

4. Manipulation by large company and stock exchange members must be resists by controlling authority.

Most important one is awareness. To make investors aware and knowledgeable SEC and Govt. should take awareness programme which is also an objective of SEC.

\section{References}

[1] Sayed, Imam Abu.(2002), "Investment in the stock market of Bangladesh: Recent selective external and monetary sector measures". Bangladesh Arthaniti Samoyiki-2004. December-2004.

[2] Imam, Mahmood Osman and Abu Saleh Mohammed Muntasir Amin .(2004). "Volatility in the stock return: Evidence from Dhaka Stock Exchange". Journal of the institute of Bankers, Bangladesh. Vol. 51, No. 1, June.
[3] Kaur, Harvinder .(2004). " Time Varying Volatility in the Indian Stock Market". Vikalpa. Vol. 29, No. 4, OctoberDecember.

[4] Kearney, Colm and Kevin Daly. (1998). "The case of stock market volatility in Australia". Applied Financial Economics. Vol. 8. pp. 597-605.

[5] Huang, Roger D. and Ronald W. Masulis. (1999). Informed Trading Activity and stock price Volatility: Evidence from London Stock Exchange". Working paper. Vanderbilt University.

[6] Schwert, G. William. (1990). "Stock Market Volatility". Financial Analysts Journal. May-June 1990.

[7] Quddus, Abdul and Selim Akhter .(1996). Price behavior of new issues listed with DSE: An analysis from the point of vie of initial subscriber. Asian Economic Review.

[8] Agundu, P.U.C. (1999). Merchant-Commercial Banks Conversion: A comparative Business Fertility Analysis. Asian Economic Review.

[9] Eilly, Frank K. and Edgar A. Norton. (1995). Investment. $4^{\text {th }}$ edition. New York: Harcourt Brace College Publishers.

[10] Ministry of Finance, GOB. (2003). Bangladesh Economic Review-2003.

[11] Ministry of Finance, GOB. (2004). Bangladesh Economic Review-2004

[12] Mishkin, Fredric S. (2001). The Economics of Money, Banking and Financial Markets. $6^{\text {th }}$ edition. Bston: AddisonWesley. 